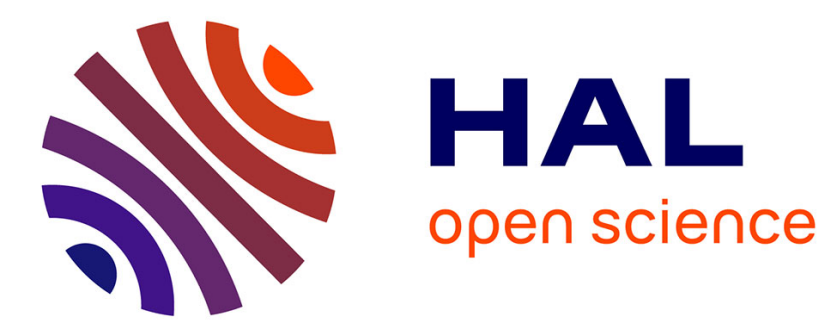

\title{
Temporal uses of Definite Articles and Demonstratives in Pomak (Slavic, Greece)
}

Evangelia Adamou

\section{To cite this version:}

Evangelia Adamou. Temporal uses of Definite Articles and Demonstratives in Pomak (Slavic, Greece). Lingua, 2011, 121 (5), pp.879-889. 10.1016/j.lingua.2010.12.001 . halshs-00556520

\section{HAL Id: halshs-00556520 \\ https://shs.hal.science/halshs-00556520}

Submitted on 17 Jan 2011

HAL is a multi-disciplinary open access archive for the deposit and dissemination of scientific research documents, whether they are published or not. The documents may come from teaching and research institutions in France or abroad, or from public or private research centers.
L'archive ouverte pluridisciplinaire HAL, est destinée au dépôt et à la diffusion de documents scientifiques de niveau recherche, publiés ou non, émanant des établissements d'enseignement et de recherche français ou étrangers, des laboratoires publics ou privés. 


\title{
Temporal uses of Definite Articles and Demonstratives in Pomak (Slavic, Greece)
}

\author{
Evangelia Adamou
}

\author{
Oral Tradition Languages and Civilizations Laboratory (LACITO), French National Center \\ for Scientific Research (CNRS), 7, rue Guy Moquet 94801, Villejuif, France \\ Tel.: +33 1.49.58.37.66; Fax: +33 1.49.58.37.79 \\ E-mail address: adamou@vjf.cnrs.fr
}

\begin{abstract}
This paper offers an analysis of the three Pomak deictics, -s-, -t- and -n-, which are used for both spatial and temporal-modal reference in nominals. This analysis is based on first-hand data from Pomak, a Balkan Slavic vernacular spoken in Greece (Xanthi prefecture). Following Culioli's framework (1971, 1978, and 1990) I propose that in this Pomak vernacular the spatial set of uses is triggered when the process situation is identical to the utterance situation (Sit2=Sit0), in which case the three deictics are organized around the distance between the referent and the speaker or the addressee, as in other person oriented systems, described e.g. by Anderson and Keenan (1985). When the process situation is different (Si2 $\neq$ Sit0) or has no relation (Sit2 $\omega$ Sit0) to the utterance situation, the temporalmodal set of uses is triggered, with a distinction between realis (with a further past vs. future distinction) vs. irrealis. These deictics also extend to clause-combining, as they partake in the formation of relative pronouns and temporal subordinators. The extensive temporal uses in Xanthi Pomak are analyzed here as an innovative use of a possibility available in the diasystem and partially encountered in other closely-related Balkan Slavic languages. Beyond the interest these data present for Slavic studies, the rich temporal uses of the Pomak deictics also contribute to typological research on overtly tensed nominals, as addressed by Lecarme (1999, 2004), and Nordlinger \& Sadler (2004).
\end{abstract}

Keywords: Deixis; Definite articles; Tensed nominals; Pomak; Balkan Slavic; Greece

\section{Introduction}

This paper analyses three deictics (-s-, -t- and -n-) used for spatio-pragmatic and temporalmodal reference in nominals in Pomak, a Balkan Slavic vernacular spoken in Greece (Xanthi prefecture). These deictics, used among others in noun modifiers such as definite articles and demonstratives, have two sets of uses, as briefly illustrated in (1a), (1b) and (1c):
(1) a. 'kote-so
cat-DEF.S
'The cat (close to the speaker, here and now).' (E-F2-30) ${ }^{1}$

\footnotetext{
${ }^{1}$ Note that when stressed the vowels /o/, /e/, /a/ are diphthongized [u'o], [j’e], [j’a]. Each example is followed by a description of the context specifying whether the example is spontaneous (S) or elicited (E). The speaker's gender, male $(\mathrm{M})$ and female $(\mathrm{F})$, is followed by an identification number valid for this paper, and by the age of
} 
b. 'kote-to

cat- DEF.A/PAST

'The cat (close to the addressee or realis past).'(E-F2-30)

c. 'kote-no

cat-DEF.D/FUT/IRR/HAB

'The cat (distal, realis future, irrealis or habitual).' (E-F2-30)

The situational anchoring framework elaborated by Culioli (1971, 1978, and 1990) can successfully account for the distribution of the spatial and temporal-modal uses of the Xanthi Pomak deictics. According to this approach the process situation (Sit2) is always related to the utterance situation (Sit0), defined by two components: the utterer, and the space and time of the utterance and the process. In this paper, I will show that in this Pomak vernacular, when the process situation is identical to the utterance situation (Sit2 $=$ Sit0) a spatial set of uses is triggered, in which case the three deictics are organized according to the distance of the referent with respect to the speaker and the addressee, as is in other person oriented systems (see Anderson and Keenan 1985). When the process situation is different (Si2 $\neq$ Sit0) or has no relation (Sit2 $\omega$ Sit0) to the utterance situation, the temporal-modal set of uses is triggered, with its realis (including a past vs. future distinction) vs. irrealis distinction, as well as the habitual (for which the realis vs. irrealis distinction is not relevant).

Whereas the three-way definite articles and demonstratives used for spatial reference are attested in other varieties of Balkan Slavic, there are no accounts of an extensive overt temporal and modal reference system such as the one described in this paper. I argue that the uses in the Xanthi Pomak vernacular should be viewed as an innovative exploitation of a possibility available in the diasystem and partially encountered in the other Balkan Slavic languages. This approach is backed by the diachronic and dialectological studies that claim that the Rhodope Mountains, where the Pomak vernacular under study is located, is the "centre of innovation in regards to the introduction of overt definiteness" (Mladenova 2007: 243 following Cyxun 1981).

Alongside the interest the Pomak deictics provide for Slavic studies, this paper offers new empirical data that further previous works on nominal temporal reference such as Enç (1986), Musan (1999), Lecarme (1999, 2004), and Nordlinger and Sadler (2004) and its implications for word classes, as discussed by Evans (2000: 711). However, it should be stressed that the temporal uses of the deictics are not always restricted to nominals but may also extend into the clausal domain, namely in Xanthi Pomak through the formation of relative pronouns and temporal subordinators (also to be found in Adamou 2010).

In section 2, I will present some linguistic and sociolinguistic information on the Xanthi Pomak vernacular. In section 3, I will present the situational anchoring framework as applied to Xanthi Pomak deictics. I will then illustrate the use of Xanthi Pomak deictics in noun modification (section 4) and in clause-combining (section 5), and give a short summary in section 6. In section 7, the Pomak data will be put in relation with other Balkan Slavic languages and, in section 8, with a number of unrelated languages in a typological perspective.

the consultant. All Xanthi Pomak data were collected by the author between 2005 and 2010 with a CNRS-Lacito funding. 


\section{Background information on Xanthi Pomak}

Pom atsko "Pomak" is the name used for the Balkan Slavic vernaculars spoken by Muslim inhabitants of the Rhodope Mountains in Greece [cf. map 1] (many of whom have recently migrated to other cities or countries). This paper is based on first-hand data of a Pomak vernacular located in the Xanthi prefecture in Greek Thrace (henceforth Xanthi Pomak) ${ }^{2}$ gathered during five fieldwork trips carried out between 2005 and 2010. The study is based on elicitation tasks and, more significantly, observation of speech production in natural contexts.

Xanthi Pomak, like other Balkan Slavic vernaculars (Rhodopean Bulgarian and Macedonian among others), has to some extent preserved a case system -distinguishing between the nominative, the dative-genitive (sg. $-u$; pl. - em), and the accusative (sg. $-a$ ), the latter also being subject to differential marking related to humanness for a number of masculine nouns and, remarkably for Slavic, for some feminine ones as well (Adamou 2009). In contrast, the closely related Standard Bulgarian and Standard Macedonian stand out among Slavic languages for using a preposition based analytical system to express those functions. Moreover, Xanthi Pomak shares some Balkan Sprachbund properties, such as the "will" future, the subjunctive, the dative-genitive merger, rare for Slavic, postposed articles, and evidentiality, at least for older speakers (see Adamou 2008; for evidentiality as a Balkan feature see Friedman 2004).

During the twentieth century, following the end of Ottoman rule and independence of the Balkan States, Pomak vernaculars in Greece had a development trajectory distinct from the closely related vernaculars spoken in the Rhodope Mountains in Bulgaria (by both Muslim and Christian populations). The Pomaks in Greece, contrary to the Bulgarian speakers of the Rhodope Mountains, have had no contact with Literary Bulgarian (except for the few years of the Bulgarian Occupation during the Second World War when Bulgarian was taught in local schools) and subsequently no influence from standardization practices (for the Rhodopean dialects' development under the influence of Standard Bulgarian see Kanevska-Nikolova 2001).

In Greece during the second half of the twentieth century, on the contrary, a massive shift from Pomak to Turkish took place, due to the fact that the Lausanne Treaty (1923) provides religious and educational rights for the Muslim Minority, including the right to bilingual Turkish-Greek primary school education. The language in the village under study is still transmitted to children and therefore the majority of the speakers are trilingual. The younger generation, both men and women, have learned Greek and Turkish at school, within the minority primary school. Elder women are sometimes monolingual in Pomak or, most frequently, also have basic communicational skills in Greek and Turkish (Adamou \& Drettas 2008).

Pomak vernaculars in Greece show significant diversity, but there is a dearth of detailed descriptions that would allow us to be more specific in terms of features and distribution. Indeed, Pomak vernaculars in Greece are still practically undescribed because, within the context of the shift to Turkish cited above, the Pomak language is the subject of strong political and ideological conflicts that make fieldwork research extremely difficult. Nevertheless, educated Pomak speakers, most often in collaboration with Greek authors, have participated in the publication of dictionaries, grammars, teaching methods for foreigners and

\footnotetext{
${ }^{2}$ Given the political pressure on Pomak speakers within a context of linguistic shift to Turkish, I have chosen not to mention the villages' names, despite the obvious interest this would present from a dialectological perspective.
} 
other materials such as folktales and songs (see Theoharidis 1995, 1996a, 1996b, 1996c, Rogo 2002, Kokkas 2004a, 2004b).

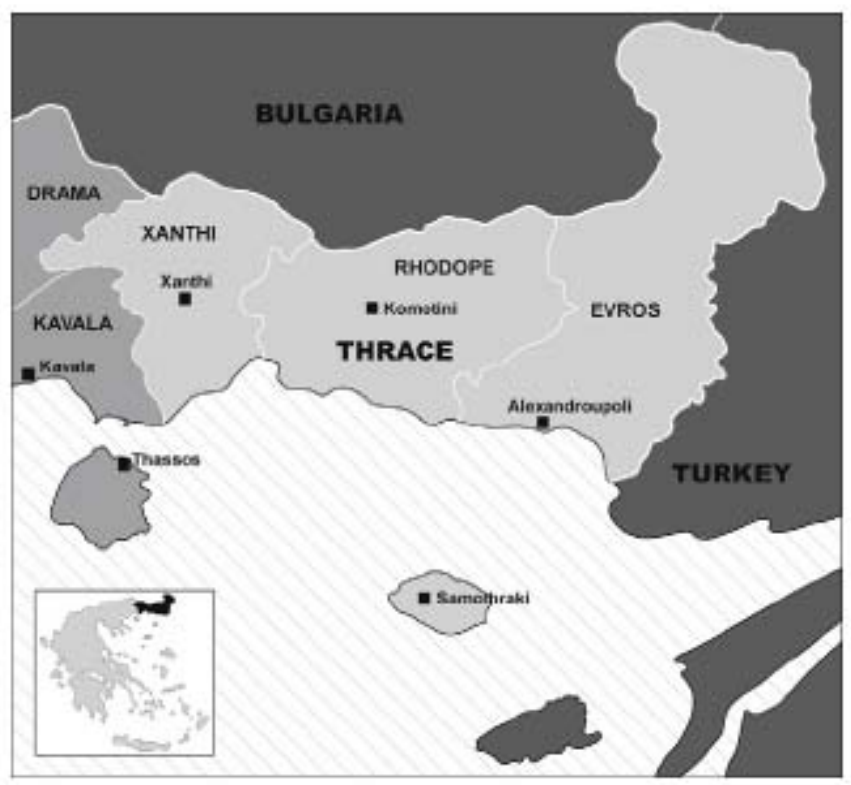

Map 1. Xanthi Prefecture in Greece

\section{Deictics in Xanthi Pomak: from location in space to location in time}

A number of scholars have drawn attention to certain frequently shared devices encoding time and space cross-linguistically. Though the debate remains open, it has been argued that space is primary as opposed to time and therefore is the category which serves as a metaphor for the other (Lyons 1977, Fleischman 1989, Heine, Claudi and Hünnemeyer 1991). The mapping of space to time has been developed for tense and aspect markers (e.g. Traugott 1978, Dahl 1985, Bybee et al. 1994), adverbials (Haspelmath 1997) and case systems (Janda 2002).

Deixis is defined by Lyons as "the location and identification of persons, objects, events, processes and activities being talked about or referred to, in relation to the spatio-temporal context created and sustained by the act of utterance and the participation in it" (Lyons 1977: 637). While deictics locate a referent in space in terms of distance from the deictic centre, their temporal uses can be viewed as locating the referent in time, following Comrie's definition of tense as a grammaticalized location in time (Comrie 1985).

The spatial and temporal uses of deictics in Xanthi Pomak will be described here in the light of the situational anchoring framework elaborated by Culioli (1971, 1978, and 1990). According to this approach, every utterance relates the utterance situation (Sit0) to the process situation (Sit2). The utterance situation is defined by the utterer, sujet énonciateur, as well as by the space and time of the utterance, while the process situation is defined by the participant in the process as well as by the space and time of the process ${ }^{3}$. The three kinds of relations between the utterance situation (Sit0) and the process situation (Sit2) that were identified by Culioli provide an adequate framework for the understanding of the Xanthi Pomak deictics' organization:

\footnotetext{
${ }^{3}$ Other major tense theories establish similar relations such as Reichenbach's framework (1947) relating the Speech Time (S), the Event Time (E) and the Reference Time (R), as well as Klein's work (1994) relating a Topic Time (defined as the time span to which the claim made on a given occasion is constrained) and the Time of Utterance.
} 
1. The process situation may be different $(\neq)$ from the utterance situation (Sit $2 \neq$ Sit0). In this case the process situation is located in the past or in future and habitual in relation to the utterance situation.

2. The process situation may be almost identical $(=)$ to the utterance situation (Sit2 $=$ Sit0), i.e. 'here and now' situations.

3. The process situation may have no relation $(\omega)$ to the utterance situation (Sit2 $\omega$ Sit0), in the sense that the process is not validated in relation to the utterance situation, nor is it validated by the author of the utterance. This is typically the case in fictional or historical narration.

The relations between Sit2 and Sit0 are often, but not uniquely expressed by tense, mood and aspect markers. In the case of Xanthi Pomak they are also expressed by the deictic suffixes in the following way:

1. Sit2 = Sit0

When the process situation and the utterance situation are almost identical (Sit2 = Sit0), the Xanthi Pomak vernacular activates the spatial-pragmatic set of deictics, with its three-way distinction relating the referent to the deictic centre; more precisely, the -s- suffix is used for a referent close to the speaker, the -t- suffix for a referent close to the addressee, and the - $n$ suffix for a referent distant from both the speaker and the addressee. Anderson and Keenan (1985) term this type of deictic system person-oriented, as opposed to distance oriented systems where the deictic centre is stable. Although deictic systems are generally described in 'close vs. distant' terms, it is broadly admitted that pragmatic parameters generally rule these systems (Levinson 2004). In order to account for such uses, the term 'personal sphere' is preferred here (Bally 1926, Marchello-Nizia 2006).

\section{Sit2 $\neq$ Sit0}

When the process situation and the utterance situation are different (Sit2 $\neq$ Sit0) the temporal set of deictic uses is activated, with its two-way distinction, namely past (expressed by the -tsuffix) vs. future (expressed by the - $n$ - suffix). The -s- suffix always corresponds to a process situation that is simultaneous with the utterance situation, and triggers the spatial distribution set described in 1.

\section{Sit2 $\omega$ Sit0}

When the process situation and the utterance situation have no relation to each other (Sit2 $\omega$ Sit0), irrealis meaning is expressed either by the - $n$ - suffix in the case of nominals and relative pronouns, or by the absence of any suffix on the temporal subordinators. This type of modal relation between Sit2 and Sit0 identified by Culioli is particularly relevant for describing the Pomak data: realis past in Xanthi Pomak is clearly distinct from irrealis.

Lastly, the -n- suffix also serves to encode the habitual for the temporal subordinator, both in future, past or situations with no relation to the utterance situation.

Table 1 below offers a first overview of these uses.

\begin{tabular}{llll}
\hline Deictic & Spatial & Temporal, Realis & Irrealis \\
& Sit $2=$ Sit0 & Sit $2 \neq$ Sit0 & Sit2 $\omega$ Sit0 \\
\hline
\end{tabular}




\begin{tabular}{|c|c|c|c|}
\hline$-S-$ & $\begin{array}{l}\mathbf{N}, \mathbf{R P r} \\
\text { speaker's sphere }\end{array}$ & N, RPr and TempS & N, RPr and TempS \\
\hline$-t-$ & addressee’s sphere & past & - \\
\hline$-n-$ & distal & $\begin{array}{l}\text { future, } \\
\text { habitual }\end{array}$ & $\begin{array}{l}\mathrm{N} \\
\text { 'habitual' in TempS }\end{array}$ \\
\hline$\varnothing$ & indefinite & indefinite & $\begin{array}{l}\text { indefinite for } \mathrm{N} \text {, } \\
\text { TempS }\end{array}$ \\
\hline
\end{tabular}

Table 1. Deictic suffixes in Xanthi Pomak: nominals ( $N)$, relative pronouns ( $R P r)$, temporal subordinators (TempS)

\section{Spatial and temporal reference in noun modification}

In Xanthi Pomak, spatial or temporal-modal reference is obligatorily expressed overtly in definite noun phrases, using either a bound ${ }^{4}$ definite article or an unbound demonstrative, or in some cases, both a definite and a demonstrative ${ }^{5}$. A distinction between demonstratives and definite articles in Xanthi Pomak is possible on the basis of their formal properties (unbound vs. bound) similarly to cross-linguistic tendencies (Diessel 1999: 129). Nevertheless, the demonstratives and the definites in Xanthi Pomak share some functional characteristics which are uncommon cross-linguistically. Although generally the definite articles lose their deictic function during the grammaticalization process and turn into formal markers of definiteness (Diessel 1999: 129), the definite articles in Xanthi Pomak keep their deictic function. Moreover, demonstratives are not restricted to a spatial and anaphoric reference but also encode a temporal reference.

\subsection{Definite articles in Xanthi Pomak}

In Xanthi Pomak, definite nouns are determined by a definite article, suffixed to the noun or the adjective as well as to the tonic possessive pronoun and to the possessive adjective. Restrictions apply for some inalienably possessed nouns as well as kinship terms, which are always definite and do not require an overtly expressed definite article (Tomić 1996: 526531). The definite article is overtly expressed when those nouns are determined by an adjective. The definite article is marked for gender (feminine $-a$, masculine $-e$ - or $-a$ - and neuter $-o$ ) and is inflected for number (singular with the three gender distinctions mentioned above, a plural - $e$ for masculine and feminine and $-a$ for neuter) and for case when appropriate (as illustrated in example 9 for deti-ne-m 'children-DEF.D(PL)-DAT/GEN').

Two sets of uses can be identified for definite articles: a first, spatio-pragmatic set is activated when the utterance situation and the process situation coincide and a second, temporal-modal set of uses is triggered when the utterance situation and the process situation are different or have no relation to each other.

\footnotetext{
${ }^{4}$ For a discussion on the status of the definite articles in Bulgarian and Macedonian see Franks and King (2000) who opt for an analysis as suffixes and Tomić (1996) who analyzes them as clitics.

${ }^{5}$ Balkan Slavic varies as to the possibility for demonstratives and definite articles to co-occur, the so called 'double definiteness' (for the distribution of double definiteness in some Balkan languages see Sobolev 2005: 243-244). The conditions of use of double definiteness in Xanthi Pomak are not fully understood and require further research.
} 
For "here and now" situations (Sit2 = Sit0), Xanthi Pomak definite articles show a three-way distinction depending on whether the referent is considered as being part of the speaker's sphere (ex. 2a), the addressee's sphere (ex. 2b), or neither (ex. 2c).

Sit2 $=$ Sit0

speaker's sphere

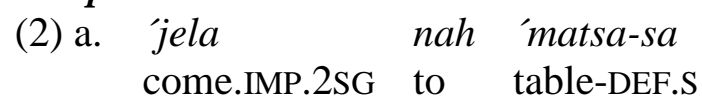

'Come to the table (speaker's sphere)!' (S-F1-4)

addressee's sphere

b. na 'matsa-ta

at table-DEF.A

'On the table (addressee’s sphere)!' (S-F1-34)

distal

c. pri 'matsa-na

next table-DEF.D

'Next to the table (distal visible or invisible)!' (S-F1-34)

The speaker's personal sphere applies to referents that are situated in the speaker's immediate vicinity, within a relative distance that allows the speaker to touch the referent in question (see Figure 1). For example in (1a), the speaker is seated next to a small table and invites the addressee, standing a little further away, to take a seat around the table.

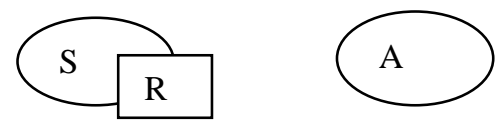

S: speaker; A: addressee; R: referent

Figure 1: The speaker's sphere

The - $t$ - article is used for a referent located in the sphere of the addressee as illustrated in Figure 2. The referent entertains the same close spatial relation to the deictic centre as the one described for the 'speaker's sphere'. In example (2b) the addressee is seated at the small table, when the speaker, sitting on a chair next to the table, asks the addressee to be careful so that the pieces of paper won't fall on the floor.
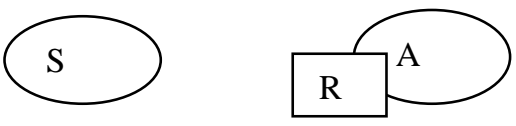

S: speaker; A: addressee; R: referent

Figure 2: The addressee's sphere

The suffix - $n$ - is used for referents that are not included in the participants' spheres. Referents that are neither in the immediate vicinity of the speaker nor of the addressee will be indexed as distal, whether visible by the speaker or not (see Figure 3). In example (2c) both the 
speaker and the addressee are far from the table, that the speaker points to in order to situate an adjacent object.

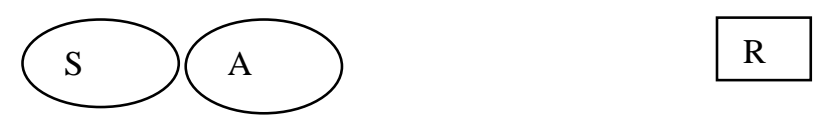

S: speaker; A: addressee; R: referent

Figure 3: Distal

The definite articles used for the speaker's and the addressee's spheres may be used for referents in tactile contact as in the examples below: in (3a) the speaker has the toothpick in her mouth as in to (3b) where the addressee has the dolly in his mouth. Similarly, in (4a) the speaker has the mobile phone in his trousers' pocket while in (4b) the addressee is wearing the t-shirt to which the speaker is referring.

\section{speaker's sphere}

(3) a. ja sam 'zøla oðodoyli'fiða-sa

1SG.NOM AUX(be).1SG took.PRF.F toothpick-DEF.S

'Me, I have gotten the toothpick (I have it on me).' (S-F3-7)

\section{addressee's sphere}

b. i'zvadi 'popka-ta

pull,out.IMP.2SG dolly-DEF.A

'Take the dolly out [of your mouth]!' (S-F3-7)

\section{speaker's sphere}

$\begin{array}{lllll}\text { (4) a. } & \text { Se } & \text { mi } & \text { 'pane } & \text { kini'to-so } \\ & \text { will } & \text { 1sG.DAT } & \text { fall.3sG mobile-DEF.S } \\ & \text { 'My mobile phone will fall!' (S-M1-8) }\end{array}$

addressee's sphere
b. bu'luz-at ti je 'hubaf
t.shirt-DEF.A 2sG.DAT is.3SG nice
'Your t-shirt (your sphere) is nice.' (S-F5-15)

The contrast between the definite articles for the addressee's sphere and for the distal sphere depends on the relative distance between the referent and the addressee. In example (5a) the speaker points to the package which is close to the addressee while asking the addressee to pass it to him. In examples (5b) and (5c) the referents are not visible to either the speaker or the addressee. In (5b) the speaker is located in front of a two-story house; the addressee is on the balcony. The speaker is referring to the entrance door which is located on the side of the house, away from both participants and not visible to either of them. The same is true in (5c) where both the speaker and the addressee are at home while the referent, the bakery, is not visible to either of them.

\section{addressee's sphere}

\footnotetext{
${ }^{6}$ There are many loan words from both Greek and Turkish in Pomak. I do not provide their origin, the Pomak morphology and syntax being respected in most cases.
} 
(5) a. daj mi kúljeta-ta

give.IMP.2sG 1SG.DAT package-DEF.A

'Give me the package (addressee’s sphere).' (S-F4-33)

distal

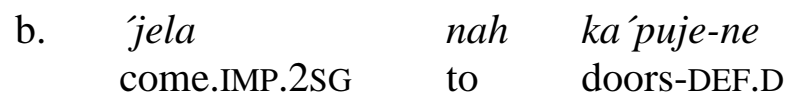

'Come to the entrance door (distal).' (S-M3-13)

c. ut 'fron-an sam 'jal ti'ropita

from bakery-DEF.D AUX(be).1SG ate.PRF.M cheese.pie

'I have eaten a cheese pie from the bakery (not located).' (S-M2-11)

In Xanthi Pomak, when the referents are located in a space and time frame distinct from the utterance situation, the temporal and modal set of uses is triggered. In this case, the addressee's $-t$ - article no longer refers to the addressee's sphere but rather to the past (see ex. $6 \mathrm{~b}$ and Figure 5), while the $-n$ - distal article is used for referents in future that have relevance to the utterance situation (illustrated in Figure 4 and in the example 6a) or in habitual situations, whether they are located in the future or in the past. In contrast, when the process situation and the utterance situation coincide, the spatial reference is triggered, as illustrated in (6c).

\section{Sit2 $\neq$ Sit0 [future]}

(6) a. na 'sfadba-na

Se 'nadena-m

tSer'ven-en

fu'stan

at wedding-DEF.FUT

will wear-1SG

red-DEF.FUT

dress

'At the wedding I'll wear the red dress.' (E-F2-30)

past

Figure 4: Sit2 $\neq$ Sit0 when Sit2 [future]

Sit2 $\neq$ Sit0 when Sit2 [past]

b. na 'sfadba-ta beh sas tfer'ven-et fu'stan

at wedding-DEF.PAST was.1sG with red-DEF.PAST dress

'At the wedding I wore the red dress.' (E-F2-30)

past future

$\mathrm{R} P$ Sit0

Figure 5: Sit2 $\neq$ Sit0 when Sit2 [past] 
Sit2 $=$ Sit0
c. na 'sfadba-sa sam / 'ima 'mnogo i'nsan
at wedding-DEF.S am.1SG / is.3SG many people
'I'm at the wedding (here and now). There are a lot of people.' (E-F2-30)

Compare (7a) for future and (7b) for past. The use of the -t- article in (7a) would imply a spatial reading, namely that the addressee is at the seaside at the time of the conversation, as in a phone conversation.

\section{Sit2 $\neq$ Sit0 when Sit2 [future]}

(7) a. 'utre $\quad$ Se var'vi-me nah déniz-en
tomorrow will go-1PL to sea-DEF.FUT
'Tomorrow we'll go to the seaside!' (E-F2-30)

\section{Sit2 $\neq$ Sit0 when Sit2 [past] \\ b. de'niz-et 'bese 't fist sea-DEF.PAST was.3sG clean \\ 'The sea was clean.' (E-F2-30)}

Contrary to other languages, and possibly to other Rhodopean vernaculars, Xanthi Pomak does not distinguish between remote and recent past reference. As the examples below show, both the remote and the recent past require the -t- suffix, as opposed to the future reference in (8c):

(8) a. la'ni déti-te mi 'beha ja'vas

last,year children-DEF.PAST 1SG.DAT were.3PL quiet

'Last year, my students were easy going.' (E-F2-30)

b. 'ftsera de'ti-te mi 'beha ja'vas yesterday children-DEF.PAST 1SG.DAT were.3PL quiet

'Yesterday my students were easy going.' (E-F2-30)

c. dugu'dina déti-ne mi 'ífta-m da sa ja'vaS next,year children-DEF.FUT 1SG.DAT want-1SG to be.3PL quiet

'Next year, I hope my students will be easy-going.' (E-F2-30)

Alongside its distal uses and future or habitual temporal reference, the $-n$ - definite article is also systematically used for definite referents in tales. One possible analysis would be to consider such uses as distal. Nevertheless, a second analysis is supported by the parallel examination of the overall organization of Xanthi Pomak which clearly distinguishes between situations that are related to the utterance situation vs. those that are not, in a modal sense. Xanthi Pomak has various means at its disposal for such distinctions, including a temporal subordinator with no deictic suffix specific to narratives and the irrealis (for a detailed analysis see section 5 - as well as the illustration in example 9 below by the use of aga 'when'), as well as grammaticalized verbal forms for evidentiality (opposed to the perfect tense by the absence of the auxiliary 'be', see Adamou 2008). In this respect, it is more likely 
that the - $n$ - article encountered in fictional narratives applies to referents that are situated in a distinct space and time frame and have no relation to the utterance situation as pictured in Figure 6.

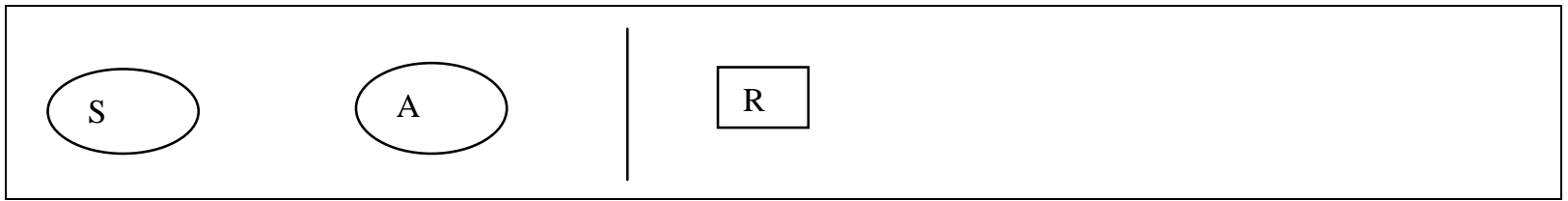

Figure 6: Sit2 $\omega$ Sit0

Sit2 $\omega$ Sit0

(9)

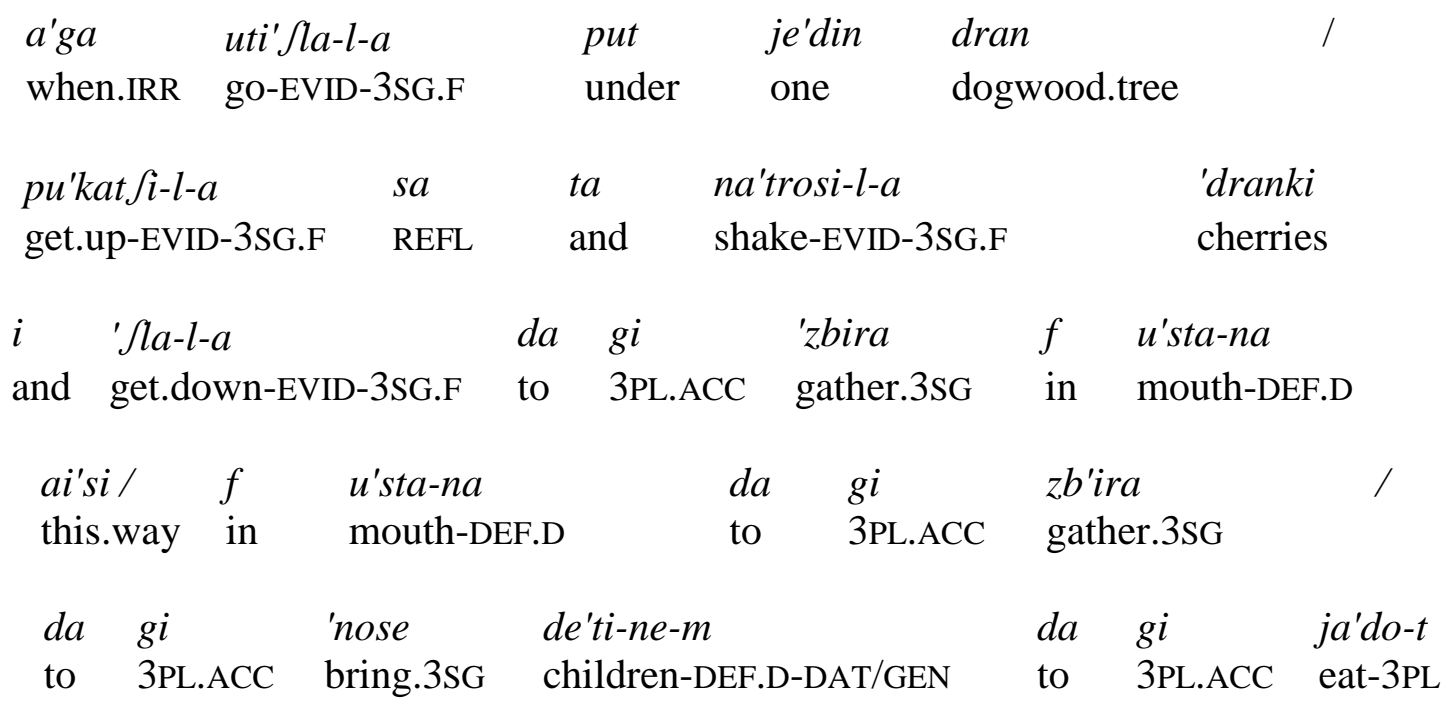

'When she went beneath a dogwood tree, she got up and shook the cherries and came down so as to gather them in her mouth, like that, so as to take them in her mouth, in order to bring them to her children to eat.'

(S-F7-66; tale on the importance of moral values and religion, in Adamou 2008)

(10) i petel't So-no 'vika kokórigo

and cock-DEF.D says.3sG kokorigo

'And the cock says 'cock-a-doodle-doo'.'

(S-F7-66; tale of an orphan-girl and her evil stepmother)

The answers to a picture task based on the Information Structure Questionnaire (Skopeteas et al. 2006) also show the exclusive use of the $-n$ - article and the total absence of the $-s$ - and - $t$ articles. In these tasks, the Xanthi Pomak speakers consider the referents in the pictures to belong to a space and time frame that are not in interaction with their own time and space frame: referents in the tasks are part of a fictional world in the same way as referents in tales are. This observation also highlights the limits of elicitation for understanding deictic systems crosslinguistically.

The example below is typical of spatial description, where the locatum (the referent whose location in space is expressed) is determined by a numeral and the relatum (the referent with respect to which the locatum is located in space) is marked by the $-n$ - definite article: 
(11) ino 'zmie je pri 'kamen-en
one snake be.3sG next stone- DEF.D

'There is a snake next to the stone.' (E-F5-18)

Similarly, the $-n$ - article is consistently used for given referents as shown in examples (12b) and (13b) ${ }^{7}$ (Leafgren 2002 considers the relation between topics and definiteness in Bulgarian as frequent though not necessary). New referents in Xanthi Pomak are generally introduced with a numeral or are without determiners.

(12) a. i'no 'skemle

one chair

'A chair.' (E-F5-18)

b. i'no 'zena 'Jiihka 'skemle-na

one woman push.3sG chair-DEF.D

'A woman pushes the chair.' (E-F5, 18)

(13) a. 'kormje

'Tree trunks.' (E-F5-18)

b. tri t/y'ljatse 'rezet 'kormje-ne

three men cut.3PL tree,trunks-DEF.D

'Three men are cutting the tree trunks.' (E-F5-18)

All the examples cited in this section show that in Xanthi Pomak definiteness and tense are obligatorily expressed through definite morphology depending on the spatial and temporal context. Tense encoded in nominals through deictics is therefore a syntactic feature that is not restricted to the category of nouns with temporal lexical semantics such as 'hour', 'day', 'week', 'month', 'year'. It is widely used with common nouns such as 'table', 'man' or 'cat', although, as is usually the case cross-linguistically (i.e., Lecarme 2004, Fenton 2010), restrictions apply to abstract entities or inalienable referents such as body part nouns i.e. 'mind' in (14a) (it could also apply to 'hand', 'arm', 'head', etc.) or kinship terms such as '(my) children' in (14b). Nevertheless, definites with temporal reference can modify some kinship terms such as 'father' when determined by a possessive adjective, as shown in (14c) (or 'husband' as shown in 16b). In some cases, for kinship nouns social deixis (Manning 2001) may prevail over spatial deixis. Compare social deixis in (14d) (the girl is located four meters away from the speaker and the addressee, a distance too far for the speaker's sphere article to be used in purely spatial terms), to the spatial deixis in (14e), where the kin relation between the referent and the speaker is expressed by the possessive.
(14) a. hit $\int$ je
'mine ne
premínalo pris
$a^{\prime} k a l$-as
at.all AUX(be).3sG 1SG.DAT NEG crossed.PRF through mind-DEF.S
'It didn't cross my mind at all!' (S-F2-30)

\footnotetext{
${ }^{7}$ Note that in the examples below, (a) and (b) correspond to the answers to sequenced pictures.
} 
b. a'ga-no mi punara'sto-t 'mufka déti-se

when-LOC.FUT 1sG.DAT grow,up-3PL a,little children-DEF.S

Se 'dojde-me nah pa'risi

MOD come-1PL to Paris

'When the (my) children grow up a little, we'll come to Paris.' (E-F2-30)

c. 'moj-et bu'bajko 'beee mih'tar

my-DEF.PAST father was.3sG mihtar

'My father was mihtar (in charge of the community's relations with outsiders).'

(S-F7-66)

d. 'polji névcesta-sa

look.IMP.2SG bride-DEF.S

'Look at the (our) bride!' (S-F8-29)

e. ka'de je tsy'ljak-an ti

where be.3SG man-DEF.D 2SG.DAT

'Where is your husband (distal)?' (S-F9-56)

Enç (1986), Musan (1999) and Lecarme (1999) raise the issue of the autonomy of nominal temporal reference in relation to verbal tense, arguing for the possibility of distinct temporal reference between the two. As Nordlinger and Sadler (2004: 779) also argue, nominal tense "provides temporal information local to the NP to which the nominal belongs. In this sense, it is functionally analogous to regular verbal tense which provides information local to the phrase headed by the verb (namely, the clause)". The temporal reference encoded by the deictics in Xanthi Pomak has similar narrow scope over the noun phrase although it generally agrees with the tense expressed overtly in the verb phrase or through temporal adverbials. Nevertheless, some arguments in favour of the syntactic and semantic independence of the nominal tense with respect to the verbal tense in Xanthi Pomak can be put forward. First, the fact that the tensed articles also occur in noun phrases, where the temporal reference is concurrently defined lexically and eventually by the pragmatic context:

(15) 'terma déniz-et

end sea-DEF.PAST

'It's over with the sea!' (S-F6-34)

The example (15) is used in a context where the speaker expresses her decision of not going to the sea in the near future. The speaker situates the 'sea' in the past through the use of the past definite article, in agreement with the lexical expression borrowed from Greek, terma 'end, over'. The verb, which is not expressed in this example, would have been in the future, thus contrasting with the NP's time reference.

Indeed, in some cases the main clause's temporal reference does not coincide with the noun's reference. For meanings such as 'former president' or 'ex-husband', Pomak combines the adjective 'former' with the past definite article -t-. The possessive relation is encoded in the dative person pronoun (in b), while the clause's future reference is encoded in the verb and in the temporal adverb 'tomorrow'. 
(16) a. mi'dyr na'prefn-et Se 'dojde 'utre

president former-DEF.PAST will come.3sG tomorrow

'The former president of the village will come tomorrow.'(E-F2-30)

b. na'prefn-et mi tfy'ljak fe 'dojde 'utre

former-DEF.PAST 1SG.DAT man will come.3sG tomorrow

'My ex-husband will come tomorrow.' (E-F2-30)

Finally, one also observes that in Xanthi Pomak the temporal uses of the deictics which modify the noun phrase also extend to clause-combining, namely to the relative pronouns' and the temporal subordinators' formation, as will be shown in section 5 , thus confirming their strong syntactic role in the language.

\subsection{Demonstratives in Xanthi Pomak}

Demonstratives in Xanthi Pomak are also distributed over the double set of uses relating the utterance situation to the process situation as well as the three-way distinction indicating the relation of the referent to the deictic centre. Demonstratives in Xanthi Pomak have both exophoric and endophoric uses (discourse deictic uses as in ex. 17c). They are unbound words inflected for gender (masculine, feminine or neuter) and number (singular or plural, with a two-way plural distinction between masculine and feminine on one hand and neuter on the other) ${ }^{8}$ and case (sg. genitive/dative aisoze, ainoze, aitoze, pl. genitive/dative aisezem, ainezem, aitezem). As can be seen in Table 2, the root morphemes -s-, $-t$ - and - $n$ - follow the epenthetic initial ai-.

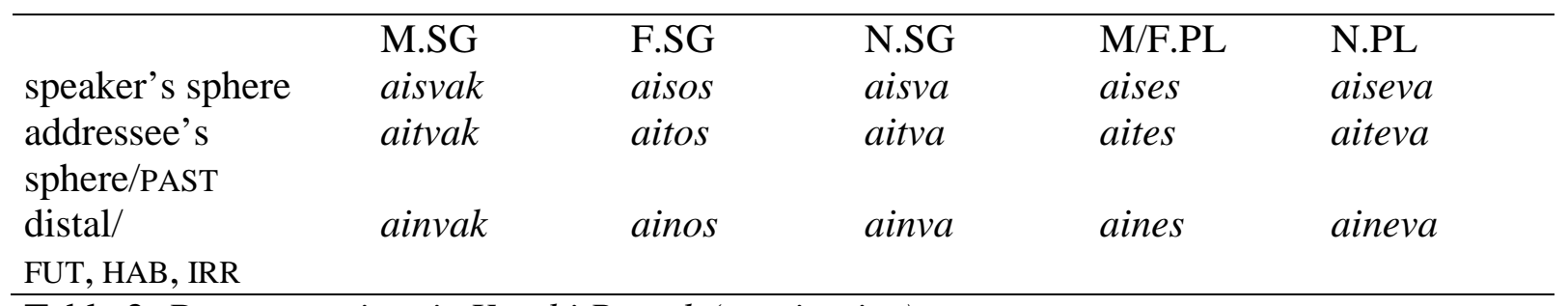

Table 2. Demonstratives in Xanthi Pomak (nominative)

Demonstratives in Xanthi Pomak can be identificational (17a), used in copula clauses; pronominal (17b), replacing a noun phrase; and adnominal (17c), with a coreferential noun (Diessel 1999). All three uses share the same form and inflectional characteristics:

speaker's sphere

(17) a. ai'sos je 'dced-va-sa 'kofta

DEM.S is.3SG grand,father-POSS-DEF.s house

'This (in my sphere) is grand-father's house.' (E-F2-30)

\section{addressee's sphere}

b. 'tsalo ait'va $\int e$ ja'de-S

all DEM.A will eat-2SG

'You'll eat all of this (in your sphere).' (S-F8-21)

\footnotetext{
${ }^{8}$ This could be an influence from Greek, as suggested to me by Eleni Buzarovska.
} 
distal

c. ai'nos 'lelka hi 'zola je 'befbin évro

DEM.D aunty DAT.3SG.F took.PRF AUX.3SG five,thousand euro

'That auntie of hers, she has got 5000 euros.' (S-F5-15)

or with the genitive case:

d. aínoze hi 'lelka

DEM.D.GEN DAT.3SG.F aunty

'That one's auntie...' (E-F5-15)

Contrary to languages where the demonstratives are purely referential (Lecarme for Somali 2004), Xanthi Pomak encodes temporal reference on the demonstratives in the same way as it does with the definite articles. Below is an example for a past moment in relation to the utterance situation agreeing with the temporal reference of the verbal predicate and the temporal adverbial napre ' $^{\prime} g \mathrm{~g}^{\prime}:$

\section{Sit2 $\neq$ Sit0 when Sit2 [past]}

(18) dve gu'dini na'pres mándili-te 'beha tsérveni

two years forward scarves-DEF.PAST were.3sG red

'oti 'befe ai'tos 'moda-ta

because was.3sG that.PAST fashion-DEF.PAST

'Two years ago, the scarves were red because that was the fashion.' (E-F2-30)

\section{Spatial and temporal deixis in clause-combining}

Expanding from the noun phrase, deictic suffixes are also used at the level of clausecombining, namely in the formation of relative pronouns and temporal subordinators. Similar uses have been described by Robert (2006) for Wolof within this same situational anchoring framework and serve to corroborate the analysis for Xanthi Pomak.

\subsection{Relative pronouns in Xanthi Pomak}

In Xanthi Pomak, relative pronouns are inflected for gender and number as shown in Table 3 below:

\begin{tabular}{|c|c|c|c|c|}
\hline & M.SG & F.SG & N.SG & PL \\
\hline speaker's sphere & 'zœs & 'zosa & 'zœso & zose \\
\hline $\begin{array}{l}\text { addressee’s } \\
\text { sphere/PAST }\end{array}$ & 'zœt & 'zœta & zœto & zote \\
\hline $\begin{array}{l}\text { distal/ } \\
\text { FUT, HAB, IRR }\end{array}$ & зæп & 'зœna & 'зœnо & 'zœne \\
\hline
\end{tabular}

Table 3: Relative pronouns in Xanthi Pomak

Relative pronouns also have two sets of uses: spatial and temporal. When the utterance situation is the same as the process situation the three-way spatial distinction prevails (close to the speaker, to the addressee or to neither of the participants): 


\section{speaker's sphere}
(19) a. gju'zlutfi-se ['zo-se 'nose-m (ai'sa)] 'jatse sa 'hubavi glasses-DEF.s which-s wear-1SG now very be.3PL nice 'The glasses that I'm wearing (now) are very nice!' (E-F5, 15)

\section{addressee's sphere}

b. gju'zlut $f$ i-te ['zo-te 'nosi- $\int$ (ai'sa)] pa'ratiki sa glasses-DEF.A which-A wear-2SG now ugly be.3PL 'The glasses that you're wearing (now) are ugly.' (E-F5, 15)

When the utterance situation is different from the process situation, the two-way temporal distinction is triggered with a past or future meaning:

\section{Sit2 $\neq$ Sit0 when Sit2 [past]}

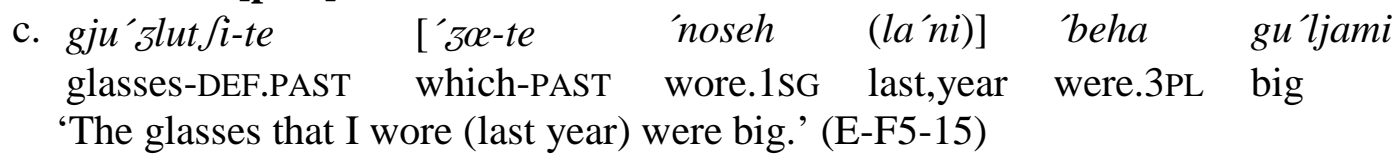

\section{Sit2 $\neq$ Sit0 when Sit2 [future]}

\begin{tabular}{|c|c|c|c|c|c|}
\hline $\begin{array}{l}\text { d. gju'zlut/i-ne } \\
\text { glasses-DEF.FUT }\end{array}$ & $\begin{array}{l}\text { ['zo-ne } \\
\text { which-FUT }\end{array}$ & $\begin{array}{l}\int e \\
\text { will }\end{array}$ & $\begin{array}{l}\text { 'kupe-m] } \\
\text { buy.1sG }\end{array}$ & $\begin{array}{l}s a \\
\text { be.3PL }\end{array}$ & $\begin{array}{l}t \int e^{\prime} r v e n i \\
\text { red }\end{array}$ \\
\hline
\end{tabular}

In (19c), the past reference coincides with the verbal tense markers of the main and the relative clauses, as well as with the temporal adverbial lani 'last year'. Example (19d) on the other hand illustrates the autonomy of nominal tense with respect to the main clause's verbal tense. More specifically, the referent 'glasses' agrees with the relative clause's verb 'will buy' and is therefore located in the future through the $-n$ - definite article, while the main clause, expressing the colour of the specific pair of glasses, is in present tense expressing a quality that exists independently of the relation between the referent and the utterance situation.

Lastly, when there is no relation between the utterance situation and the process situation, the - $n$ - relative pronoun is used, as illustrated in the following utterance from a picture description task:

\section{Sit2 $\omega$ Sit0}

$$
\begin{aligned}
& \text { (20) i'no tfy'ljak ['zoe-n se'di] } \\
& \text { one man who-D sit.3sG } \\
& \text { 'A man who is seated'. (E-F5-18) }
\end{aligned}
$$

\subsection{Temporal subordinators in Xanthi Pomak}

The deictic suffixes participate in the formation of temporal subordinators in Xanthi Pomak which express reference to the utterance situation and to the process situation in the following way: ${ }^{9}$

\footnotetext{
${ }^{9}$ This is not a unified analysis for all the Rhodope varieties using deixis in the temporal conjunctions. Observations based on short term fieldwork in a Pomak variety in the Evros department in Greece, show a different system whose understanding requires further research (fieldwork notes Adamou 2005-2006).
} 
The presence of a deictic suffix indicates that the process is anchored in the utterance situation, while the choice of the deictic suffix indicates the type of relation between the process situation and the utterance situation. The -t- suffix is used for past (illustrated in 21a) and the - $n$ - suffix for habitual and future (see examples $21 \mathrm{~b}$ and 21c), in accordance with the temporal uses of the definite articles, demonstratives and relative pronouns. A temporal subordinator with the -s- suffix is not attested in Xanthi Pomak though in the Rhodope dialects in Bulgaria, gasu is in use (p.c. Kanevska-Nikolova). Whenever the utterance situation and the process situation are unrelated, typically for irrealis situations such as in folktales, the temporal subordinator bears no deictic suffixes (see 21d and Adamou 2010 for more details). Nevertheless, in case of a habitual situation in irrealis, the habitual temporal subordinator agano will be used instead of aga; the feature 'habitual' ranking higher in the hierarchy than the irrealis feature.

\section{Sit2 $\neq$ Sit0 when Sit2 [past]}
(21) a.
[a'ga-to
fprce ]
kofta-ta
be
izgo'rjala
when-PAST arrived.1SG
house-DEF.PAST AUX.3SG
burned,down.P.PRF
'When I arrived, the house had burned down.' (On a past event) (E-F8-21)

\section{Sit2 $\neq$ Sit0 when Sit2 [habitual]}

b. [a'ga-no u'mre bu'nno] ni 'prave-t 'volta when-HAB die.3SG someone NEG make-3PL walk

'Whenever someone dies, they don't take a walk.' ${ }^{10}$ (E-F2-30)

\section{Sit2 $\neq$ Sit0 when Sit2 [future]}

kug'a-no is a variant used by younger speakers:
c. [ku'ga-no 'dojde] Se $[h] i$
$g u$
'onesa-m
when-FUT come.3SG will 3sG.F.DAT 3SG.M/N.ACC bring-1SG
'When she comes, I'll bring it to her.' (S-F5-15)

\section{Sit2 $\omega$ Sit0 when Sit2 [irrealis] \\ d. [a'ga sa 'vornal-i dve gu'dini 'setne ud ala'manie] when.IRR REFL return.EVID-3PL two years after from Germany \\ uti'תlil-i da pla'tz-t jaj'tsa-na \\ go.EVID-3PL to pay-3PL eggs-DEF.D \\ 'When they returned two years later from Germany, they went to pay for the eggs.' (S-M3-70, Nasredin Hodja story)}

Interestingly, the irrealis subordinator is also used for conditional clauses, in parallel with the more frequent $a k u$.

$$
\begin{aligned}
& \text { a'ga ni '́poje-m 'nema da 'ida-m faf panepi'stimjo } \\
& \text { if NEG study-1SG not,have.3SG to go-1SG in university } \\
& \text { 'If I don't study, I won't go to the university.' (E-F3-7) }
\end{aligned}
$$

\footnotetext{
${ }^{10}$ This term refers to a special social event that takes place in the afternoon, when unmarried girls walk in the main village street in front of the boys in order to make a potential match. This walk takes place in two villages in the area and attracts young people from the surrounding villages.

${ }^{11}$ kuga is not attested in my corpus.
} 


\begin{tabular}{|c|c|c|}
\hline$a^{\prime} g a$ & $\begin{array}{l}\text { "when" } \\
\text { "if" }\end{array}$ & $\begin{array}{l}\text { Sit2 } \omega \text { Sit0 [irrealis] } \\
\text { (conditional) }\end{array}$ \\
\hline$a^{\prime}$ gato/ku'gato & "when" & Sit2 $\neq$ Sit0 when Sit2 [past] \\
\hline$a^{\prime \prime g a n o / k u ' g a n o ~}$ & $\begin{array}{l}\text { "when” } \\
\text { "whenever” }\end{array}$ & Sit2 $\neq$ Sit0 when Sit2 [future, habitual] \\
\hline
\end{tabular}

Table 4. The temporal subordinating conjunctions in Xanthi Pomak

As discussed in Adamou (in press) the interclausal relation is determined both by the subordinators and the tense-mood-aspect markers. Indeed, the three temporal markers presented above are not specialized in a specific type of temporal interclausal relation: for example agato is used for anteriority, posteriority, simultaneity, terminus a quo, while all three markers can express anteriority. Similarly to noun determiners, the deictics used in temporal subordinators are independent from the clause's tense-aspect-mood markers:

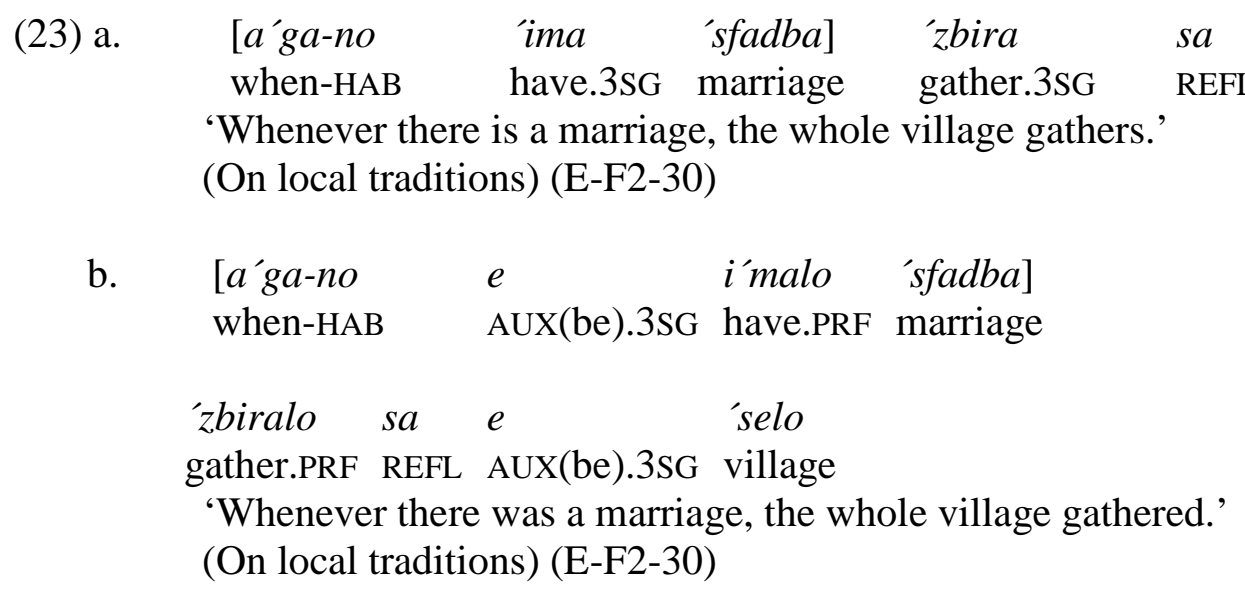

\section{Summary: Deixis in Xanthi Pomak}

To summarize, the Pomak vernacular under study is firmly organized around the speech situation's space and time, triggering either a set of uses encoding spatial reference or a set of uses encoding temporal and modal reference. It has been shown how the three deictic suffixes form the definite articles, demonstratives, relative pronouns and temporal subordinators. In Pomak as spoken in the Xanthi prefecture, for "here and now" situations, the entities considered as belonging to the speaker's sphere receive the -s- suffix, while the -t- suffix is used for the addressee's sphere, and the -n- suffix for the distal sphere.

When the entities are located in a different space and time frame, but are related to the utterance situation (Sit0), the -t- suffix is no longer used for the addressee but for an entity in the past as compared to the time of the utterance situation. The - $n$ - suffix is used for entities in future, generic or habitual situations and for cases where no relation exists between the utterance situation (Sit0) and the process situation (Sit2), e.g. in tales.

These uses help us to understand the equally rare uses in Slavic of these two deictic suffixes to form temporal subordinate conjunctions anchoring events in the utterance situation. As shown in Adamou (in press), a'gato/ku'gato 'when (past)' is used for a past moment in relation to the utterance situation. A'gano/ku'gano 'when, whenever', denotes future moments in relation to the utterance situation, as well as habitual events, whether in relation or not to the utterance situation. Absence of these deictics indicates absence of anchoring in the utterance situation; $a g^{\prime} a$ 'when (no anchoring)' is thus used in fictional narratives. 
Figure 8 illustrates the various spatial and temporal uses:

\section{Sit2 $\omega$ Sit0}

$\varnothing$ suffix for temporal subordinators

HABITUAL

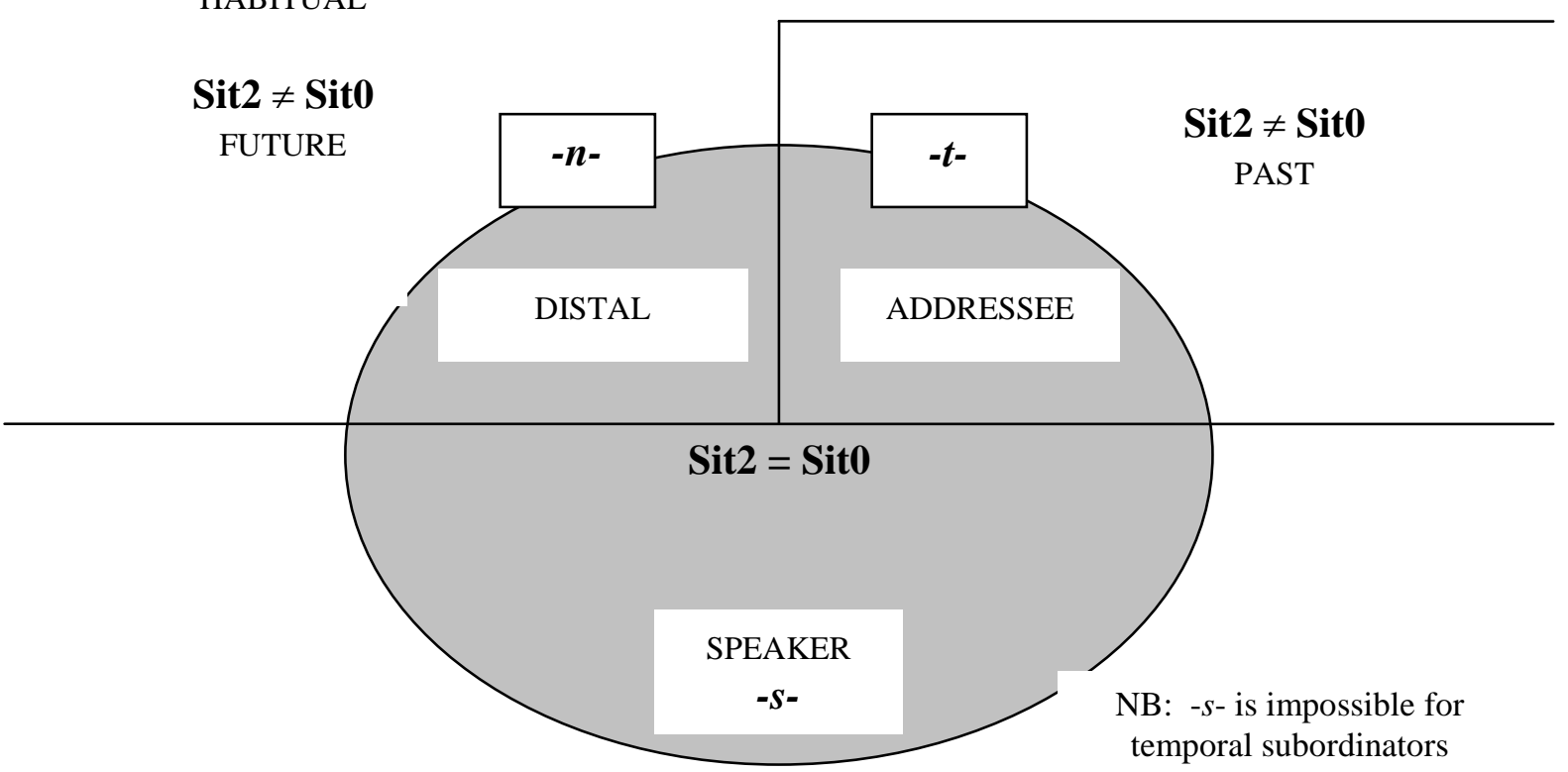

Figure 8: A map of spatial and temporal deixis in Xanthi Pomak

\section{Xanthi Pomak deictics within Balkan Slavic}

Definite articles are rare within the Slavic languages: they have only been grammaticalized in Balkan Slavic languages, while their grammaticalization in some vernaculars in North Russia is controversial (see Breu 1994, Kasatkina 2008). From an areal perspective, postposed articles are a well-known Balkan Sprachbund feature -shared by Romanian, Aromanian and Meglenoromanian, as well as Albanian- even though their development is probably equally influenced by each language's diachrony as well as by their mutual reinforcement through multilingualism (Asenova 2002).

As is generally admitted, definite articles are grammaticalized from demonstratives (Diessel 1999, Lyons 1999). In the case of South Slavic, written sources show that, by the thirteenth century, the postposed Old Church Slavonic ${ }^{12}$ demonstratives were grammaticalized into clitic demonstratives, and then into clitic articles: see Flier (1974), Gălăbov (1950), Svane (1961, 1962), Mirčev (1964) or more recently Dimitrova-Vulchanova and Vulchanov (in press); for a discussion on their status in the modern languages see Elson (1976); and for a detailed diachronic model of definiteness in Bulgarian see Mladenova (2007).

Some Balkan Slavic languages use a single definite article, usually based on the $-t$ - form: this is the case in Standard Bulgarian and many Bulgarian vernaculars, as in the Eastern Macedonian vernaculars and the vernaculars spoken in Western Greece. The existence of two-fold definite systems is controversial (for a critical analysis see Mladenov 1990). Three-

\footnotetext{
12 Old Church Slavonic [OCS] refers to the oldest available Slavic documents, mostly ecclesiastical. OCS extends from the 9th to the 11th century and is classified as South Slavic.
} 
way definite articles are to be found in three geographic areas (as can also be seen in Map 2): in most, but not all, of Western Macedonian vernaculars that served as the norm for Standard Macedonian; in most, though not all, of the vernaculars of the Rhodope Mountains (in Bulgaria and Greece), and also in some vernaculars spoken in Eastern Serbia (Torlak).

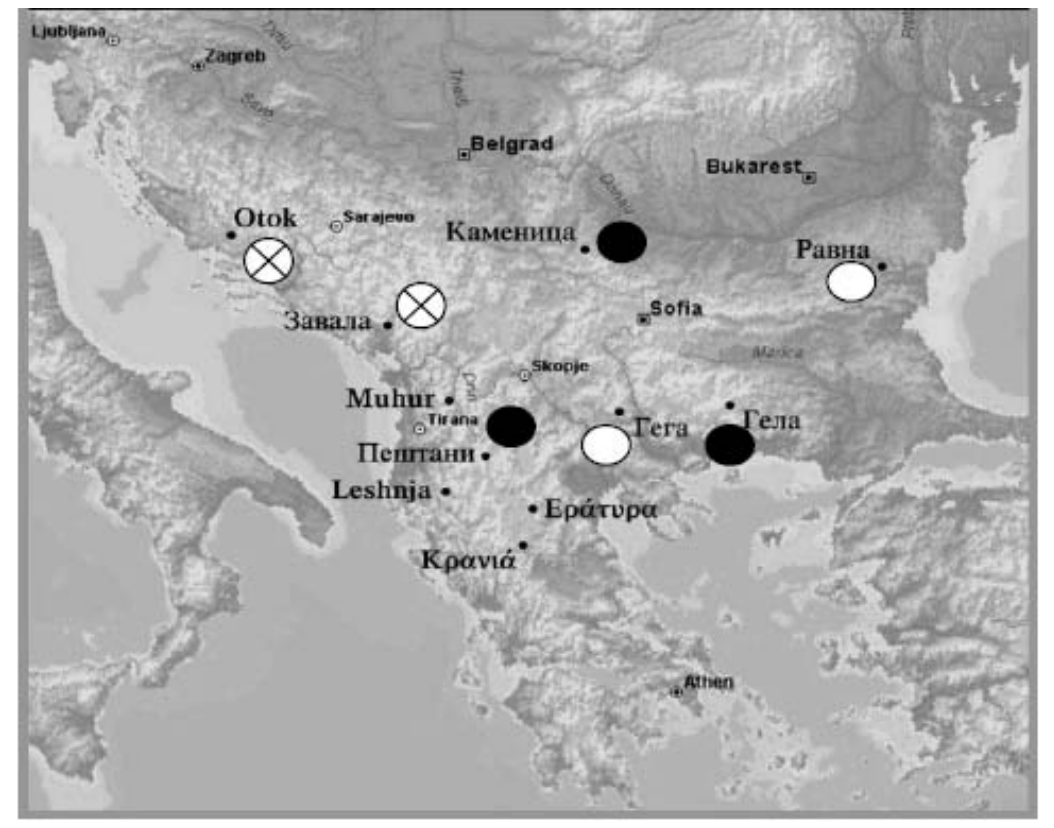

three-way article
single article
no article

Map 2. The distribution of the definite articles in Balkan Slavic after the Small Atlas of Balkan Languages (Sobolev 2005: 242)

Although the three-way definite article is traditionally considered in the literature as a "conservative” feature (Miletič, Koneski, Cyxun) according to which all Balkan Slavic went through a phase of grammaticalization of three definite articles and then reduced them to a single definite one; divergent analyses argue convincingly that the three-way definite articles are innovations in specific vernaculars and did not develop uniformly in all the Balkan Slavic languages (Mladenova 2007: 319-325 also quoting Velčeva-Bojadžieva and Šaur).

It is important to note that the number of demonstratives and definite articles varies across Balkan Slavic. For example, while the Xanthi Pomak variety under study and Standard Macedonian have a three-way distinction for definite articles and demonstratives, in other Xanthi Pomak vernaculars (Kokkas 2004a: 22), demonstratives form a two-way system based on a 'close-distant' spatial contrast, ${ }^{13}$ whereas the definite articles form a three-way personoriented system. In the same way, Standard Bulgarian has a two-way demonstrative system, the -t- suffix being used either as proximal (when contrasted) or as unmarked as far as distance is concerned, while the - $n$ - suffix indicates distance.

It is not clear whether the three-way definite systems in Balkan Slavic are person or distance oriented, since the descriptions vary according to the authors, making it difficult to judge whether this variation is due to divergent analyses or to the systems themselves. Kanevska-

\footnotetext{
13 In the geographically close variety of Pomak described in Kokkas (2004) the demonstratives are the following: izí (m.), isáy (f.), izí, isáy (n.) and iséy (pl.) for close entities, inazí (m.), ináy (f.), inazí, ináy (n.) and inéy (pl.) for distant entities.
} 
Nikolova (2006: 79) for example describes the Rhodope definite system as what can be named, after Anderson and Keenan's (1985) terminology, a distance oriented system (the speaker being its centre, in pragmatic or spatial terms). On the contrary, in Mladenova (2007: 318) the Rhodope system is clearly described as person-oriented. Most descriptions of Literary Macedonian also centre its system on the speaker see Table 5 (Lunt 1952: 40-41; Minova-Gurkova 1997, Friedman 2002; and for a different analysis Topolinjska 2006 relating definiteness and factivity) though according to Koneski (1954) and Tomić (1996) they are person oriented.

\begin{tabular}{ll}
\hline$-f / v-$ & close to the speaker \\
$-t-$ & unmarked (no indication of distance) \\
$-n-$ & away from the speaker
\end{tabular}

Table 5. Deictic suffixes in Standard Macedonian definite articles

A similar split is found in the analyses of Old Church Slavonic demonstratives: for example, in Vaillant (1964: 140) and Flier (1974) the system appears to be distance-oriented while in Feuillet (1999: 148) it is described as person-oriented. According to Marchello-Nizia (2006) this sort of distinction could indicate different states of the language and is thus important to specify ${ }^{14}$.

Next to their spatial uses, it is important to note that temporal uses have been described to some extent for definite articles in other Balkan Slavic languages. Lunt (1952) and Koneski (1954) mention in Literary Macedonian some temporal uses for the definite articles that determine a small number of nouns with temporal meaning: "godinava, zimava, utrinava and letovo mean 'this (current) year winter, morning, summer"' (Lunt 1952: 21). Sobolev (2005: 245) also confirms these uses for Rhodopean from Gela.

Moreover, some authors have mentioned some non-deictic, non-spatial uses for the Macedonian definite articles. Tomić (1996) distinguishes the uses of present vs. absent referents: "The members of the t-set refer to non-present objects, as well as present objects which are proximate to the addressee [...] the members of the v-set refer to present objects which are proximate to the speaker [...] whereas the members of the n-set refer to present objects which are remote from both the speaker and the addressee [...]" (Tomić, 1996: 513). More recently, based on a textual analysis, Sonnenhauser (2009) suggests that the Macedonian definite articles are also used as a perspectivizing strategy. She shows for example that the proximal article supports the author's perspective while the unmarked article serves to distanciate the author from the event.

Alongside definite articles and demonstratives, deictic suffixes are also used in adverbials in many Balkan Slavic languages. In Xanthi Pomak, the three deictic suffixes -s-, -t-, -n-, are used on comparison markers ( $k a^{\prime} k s o$ / ka'kto / ka'kno "as") and quantifiers (aiso'lkos / aito'lkos / aino'lkos "this much", "that much") while they can be partially encountered on manner adverbs (ai'si "this way" / aíni "that way"). Similar uses are found in Standard Macedonian for qualitative and quantitative adjectives (Lunt 1952: 47) and for manner adverbs, vaka / taka / onaka (Lunt 1952: 52).

Nevertheless, the extensive use of deictics in temporal subordinators is clearly a less common feature and Mladenova (2007: 242) considers it a recent innovation. Based on the study of Damaskin $^{15}$ texts Mladenova shows that temporal conjunctions are primarily (96.88\%) used

\footnotetext{
${ }^{14}$ As one reviewer pointed out, although the Xanthi Pomak spatial uses might be person-oriented, the temporal uses are centered on the speaker.

${ }^{15}$ Translated literary texts of a religious and didactic nature, combining Church Slavonic and what is referred to as Modern and, for some of them, Middle Bulgarian (17th-18th centuries).
} 
without deictic suffixes, i.e. koga, (e.g. in Standard Macedonian) with a single use of kogato "when" (e.g. in Standard Bulgarian).

The formation of relative pronouns and temporal subordinators with deictic suffixes has been reported for Rhodopean although their uses are not fully understood. Following existing dialectological work, Krapova (2010: 1241), mentions such uses for the relative marker (i.e. deto, deno, deso) as phonological variations. The data from Shiroka Luka (Bulgaria) (Sobolev 2001) show the formation of the temporal subordinators with the three deictic suffixes, but their meanings are not fully understood and require further research in order to test the analysis suggested by the Xanthi Pomak data in this paper. It would therefore be interesting for future research to work, among other subjects, on existing descriptions of Rhodopean (i.e. Kabasanov's description of Tixomir 1963) in order to comprehend the various uses and eventually suggest a unified analysis.

It is also difficult at this stage to account for all the differences in the use of deictics in Balkan Slavic: why do some languages have mixed systems with two-way distinctions for demonstratives and three-way distinctions for definite articles; why do some languages use the deictics for relative pronouns and temporal subordinators but not others; why have some languages developed extensive temporal uses and others on the contrary restricted them? Language contact could be a tempting means to account for such differences. For instance Xanthi Pomak has had long-term contact with Turkish which also has a three-way distinction for demonstratives. Nevertheless, Turkish influence cannot explain the use of deixis in the Xanthi Pomak definite articles (Turkish has no definite article and marks definiteness through case marking or word order) or in temporal subordinators. The most appropriate analysis seems to be that the temporal uses of the deictics in Xanthi Pomak are an innovative development of an existing possibility in the diasystem: from demonstratives to grammaticalized definite articles, the deictics are also used in number of adverbials and have spread to clause-combining, namely relative pronouns and subordinators, at varying rates and to different extents, depending on the vernaculars. The Rhodope area is the center for overt definiteness (according to Cyxun 1981 and Mladenova 2007), thus one would expect it to be the most advanced as far as the development of overt deixis is concerned.

\section{Xanthi Pomak deictics in a cross-linguistic perspective}

The spatial and temporal uses of definite articles and demonstratives in Xanthi Pomak, although rare for Slavic languages, are encountered in a number of unrelated languages. Numerous language descriptions point to this sort of phenomena but a cross-linguistic survey is not yet available, though temporal uses were mentioned in all the cross-linguistic studies on deixis such as Anderson and Keenan (1985), Diessel (1999) and in Nordlinger and Sadler (2004: 787) within a larger study on nominals inflected for tense, mood and aspect. A short comparison of the Pomak data with those available for other languages will be presented here in order to better situate the phenomenon in a typological perspective.

Unlike Xanthi Pomak, temporal encoding in noun phrases is expressed in some languages by a number of specialized definite articles or demonstratives. This is the case of the definite articles in Somali (Lecarme 1999, 2004), which encode a temporal [ \pm past] distinction, alongside the four demonstratives that are restricted to spatial reference. Likewise, definite articles are found to express a [ \pm past] temporal reference in the Chamicuro languages of Peru (Arawak), as shown in Parker (1999): 


\author{
Chamicuro \\ (25) a. p-aškala?t-is-na čamálo \\ 2-kill-2.PL-THE bat \\ 'You (plural) are killing the bat.' (Parker 1999: 553) \\ b. p-aškala?t-is-ka čamálo \\ 2-kill-2.PL-THE(PAST) bat \\ 'You (plural) killed the bat.' (Parker 1999: 553)
}

In Mojeño Trinitario (Arawak), two of the six available demonstratives seem to be related to tense and mood: "Demonstratives in -kro almost always refer to some irrealis referent (a future or hypothetical referent, as in 'he/this one will come'), while demonstratives in -ñgi often refer to referents of the past, or not present any more in the speech event ('in those years', 'that man (that passed by earlier)').” (Rose in press). Three different demonstratives are restricted to spatial relations and a fourth one is used for anaphora.

Similarly to Xanthi Pomak, in some languages the articles or the demonstratives combine a temporal and a spatial reference. This is the case for Movima (Bolivia, unclassified), described by Haude (2006: 159). A first article is used for presential or non-past, a second for absential or immediate past and a third one solely for past. Bril (2002: 276) shows that in Nêlêmwa (Oceanic), the deictics -suffixed to nouns, personal pronouns and demonstratives among others- have a rich variety of spatial or temporal relations. The proximal is used for the present, the middle for the immediate prospective, the distal for the distal prospective. The anaphoric demonstrative corresponding to a referent which is known by the speaker is not temporally marked, and the demonstrative which corresponds to a referent known by the addressee is used for past (immediate or remote). Lastly, the demonstrative used for indicating that the spatial distance is unknown also denotes an uncertain future. For Pilagá and Toba? (Guaykuruan) it is argued by Vidal and Klein (1998) that the distal markers ga' in Pilagá and $k a$ in Toba?, attached to demonstratives and nouns among others, also express, by semantic extension, a hypothetical or unrealized event. In Zapotec (Otomanguean), Fenton (2010) also shows a spatial-temporal relation for one of the determiners, the distal/invisible $k i$ which is equally used for past reference. A more detailed distinction between remote past (through the invisible) and close past (through the proximal) is also discussed (Fenton 2010: 136).

In Wolof (Niger-Congo), Robert (2006) shows how the deictic suffixes largely organize the language by combining spatial and temporal reference for the predicate and the subordination, though they do not encode temporally the nouns (see Table 6).

Localization (in space, time or discourse) relative to the speaker

\begin{tabular}{llll}
\hline & proximity & distance & absence \\
\multirow{4}{*}{ Noun } & $-i$ & $-a$ & $-u$ \\
& proximal & distal & indefinite \\
& definite & definite & relative/interrogative \\
Predicate & proximal & distal & negation/passive \\
& present & present & \\
Subordination & close past & remote past & future/hypothetical \\
\hline
\end{tabular}

Table 6. Semantics and uses of deictic affixes in Wolof (Robert 2006: 168)

At this stage, it is difficult to draw any cross-linguistic tendencies for the mapping of space and time as expressed by deictic suffixes. Nordlinger and Sadler (2004: 800-801) note some 
tendencies towards nominal tense based on a wide range of languages. They show that tense is the first distinction to be encoded in nominals, with the past vs. non-past distinction being the minimal one. Further distinctions can be made for mood but no distinctions have been found for aspect. The small sample of languages presented above, and summarized in Table 7, shows that although the proximal is often used for the present and the distal for hypothetical and future reference, more subtle distinctions are encoded for the various types of past (close, remote) and future (immediate, distal). This small sample also shows that in some languages the same deictics are used to encode both temporal and spatial reference (Pomak, Nêlêmwa, Movima) while in others they specialize in either one or the other (Mojeño Trinitario, Somali). Moreover, tense encoded through deictics can co-occur with verbal tense (Pomak, Somali) or, more rarely, it can express tense on its own (Chamicuro). Further research is clearly needed on this topic in order to draw some conclusions as to the encoding of space and time across the world's languages.

\begin{tabular}{|c|c|c|c|c|c|}
\hline Language & Family & Space \& & Time & & \\
\hline Zapotec & Otomanguean & $\begin{array}{l}\text { proximal/ } \\
\text { near past }\end{array}$ & & $\begin{array}{l}\text { distal, invisible/ } \\
\text { remote past }\end{array}$ & \\
\hline Movima & $\begin{array}{l}\text { Unclassified } \\
\text { (Bolivia) }\end{array}$ & $\begin{array}{l}\text { presential/ } \\
\text { non-past }\end{array}$ & $\begin{array}{l}\text { absential/ } \\
\text { immed.past }\end{array}$ & past & \\
\hline Nêlêmwa & Oceanic & $\begin{array}{l}\text { proximal/ } \\
\text { present }\end{array}$ & $\begin{array}{l}\text { middle/immed. } \\
\text { prospective }\end{array}$ & $\begin{array}{l}\text { distal/distal } \\
\text { prospective }\end{array}$ & $\begin{array}{l}\text { unmarked } \\
\text { /uncertain } \\
\text { future }\end{array}$ \\
\hline $\begin{array}{l}\text { Pilagá, } \\
\text { Toba? }\end{array}$ & Guaykuruan & & & $\begin{array}{l}\text { distal/hypothetical, } \\
\text { unrealized }\end{array}$ & \\
\hline Pomak & Slavic & $\begin{array}{l}\text { speaker/ } \\
\text { present }\end{array}$ & addressee/past & $\begin{array}{l}\text { distal/future, } \\
\text { habitual }\end{array}$ & Ø/irrealis \\
\hline Wolof & Niger-Congo & $\begin{array}{l}\text { proximal/ } \\
\text { near past }\end{array}$ & & distal/remote past & $\begin{array}{l}\text { indefinite/ } \\
\text { future- } \\
\text { hypothetical }\end{array}$ \\
\hline
\end{tabular}

Table 7: Time and space reference in deictics in a small number of languages

\section{Summary and conclusion}

The study of the Pomak vernacular spoken in the Xanthi prefecture (Greece) reveals an interesting use of the definite articles and demonstratives for temporal and modal reference, alongside their more well-known spatial reference in Balkan Slavic. The analysis of the Pomak data within Culioli's situational anchoring framework allows the identification of the parameters that trigger either the temporal or the spatial set of uses, namely the relation between the process situation (Sit2) and the utterance situation (Sit0). On one hand, a threeway spatial distinction is encoded in nominals when the utterance situation and the process situation coincide (Sit2=Sit0). On the other hand, temporal reference is triggered when the process situation is different from the utterance situation, $\operatorname{Sit} 2 \neq \operatorname{Sit} 0$ (realis mode), with a past vs. future distinction, or when there is no relation between the process situation and the utterance situation, Sit2 $\omega$ Sit0 (irrealis mode). This temporal reference does not apply only to the noun phrases but also extends to larger syntactic domains and more specifically to clausecombining with the formation of relative pronouns and temporal subordinators (Adamou 2010). This extensive use of deictics for temporal reference is a rare phenomenon among Slavic languages, even though it could prove to be a more common one cross-linguistically. More research is needed, both from a synchronic and a diachronic perspective, on this phenomenon that hitherto has received no attention in Slavic studies. 


\section{Abbreviations}

ACC - accusative; AUX - auxiliary; DAT/GEN -dative/genitive; DEF.A - definite addressee's sphere; DEF.D - definite distal; DEF.S - definite speaker's sphere; E - elicited; EVID - evidential; F - female; FUT - future; HAB - habitual; IMP - imperative; IRR irrealis; PAST - past; M - male; MOD modality; N - neuter; NEG - negation; POSS - possessive; PRF - perfect; P.PRF - past perfect; REFL - reflexive; $\mathrm{S}$ - spontaneous

\section{Acknowledgements}

I wish to acknowledge the financial support of the CNRS-Lacito laboratory that made possible all the field work trips on which the present research is based. I would like to thank the four anonymous reviewers of Lingua; their extensive remarks raised several interesting theoretical issues which allowed me to improve significantly the initial version of the paper. Many thanks as well to the Pomak speakers who kindly accepted to teach me their language.

\section{References}

Adamou, E., 2008. Sur les traces d'une dégrammaticalisation: le médiatif en pomaque (Grèce). Revue des Études Slaves: Pre-proceedings of the French delegation at the XIV International Congress of Slavists 78/1-2, 177-189.

Adamou, E., 2009. Le marquage différentiel de l'objet en nashta et en pomaque (Grèce). Retour sur l'hypothèse du contact. Bulletin de la Société de Linguistique de Paris 104/1, 383-410.

Adamou, E., 2010. Deixis and temporal subordinators in Pomak (Slavic, Greece). In: Bril, I., (Ed.), Clause-Linking and Clause-Hierarchy. Benjamins, Amsterdam/Philadelphia, pp. 399-420.

Adamou, E., Drettas, G., 2008. Slave. In: Adamou, E., (Ed.), Le patrimoine plurilingue de la Grèce. Peeters, Louvain/Paris, pp. 107-132.

Anderson, S. R., Keenan, E. L., 1985. Deixis. In: Shopen, T., (Ed.), Language, Typology and Syntactic Description. Cambridge University Press, Cambridge, pp. 259-308.

Asenova, P., 2002 [1st edition 1989]. Balkansko ezikoznanie. Faber, Veliko Tŭrnovo.

Bally, C., 1926. L'expression des idées de la sphère personnelle et de solidarité dans les langues indo-européennes. In, Fankhauser, F., Jakob, J., (Eds.), Festschrift Louis Gauchat. Verlag Sauerlander, Aarau, pp. 68-78.

Breu, W., 1994. Der Faktor Sprachkontakt in einer dynamischen Typologie des Slavischen. In: Mehlig, H. R., (Ed.), Slavistische Linguistik 1993. Verlag Otto Sagner, Muenchen, pp. 41-64.

Bril, I., 2002. Le nêlêmwa (Nouvelle-Calédonie) : Analyse syntaxique et sémantique. Peeters, Louvain/Paris.

Bybee, J., Perkins, R., Pagliuca, W., 1994. The evolution of grammar. The University of Chicago Press, Chicago.

Comrie, B., 1985. Tense. Cambridge University Press, Cambridge.

Culioli, A., 1971. À propos d'opérations intervenant dans le traitement formel des langues naturelles. Mathématiques et Sciences humaines 34, 7-15.

Culioli, A., 1978 [1983]. Valeurs aspectuelles et opérations énonciatives : la notion d'aoristique. In: Fisher, S., Franckel, J. J., (Eds.), Enonciation: Aspect et détermination. EHESS, Paris, pp. 99-114. 
Culioli, A., 1990. Pour une linguistique de l'énonciation. Opérations et représentations. Ophrys, Paris/Gap.

Cyxun, G. A., 1981. Tipologičeskie problemy balkanoslavjanskogo jazykovogo areala. Nauka i texnika, Minsk.

Dahl, Ö., 1985. Tense and aspect systems. Blackwel, Oxford.

Diessel, H., 1999. Demonstratives. Form, function and grammaticalization. John Benjamins, Amsterdam /Philadelphia.

Dimitrova-Vulchanova, M., Vulchanov, V., In press. An Article Evolving. In: Anderson, S., Jonas, D., (Eds.), DIGS Volume. Oxford University Press, Oxford.

Elson, M. J., 1976. The definite article in Bulgarian and Macedonian. Slavic and East European Journal 20, 273-9.

Enç, M., 1986. Towards a referential analysis of temporal expressions. Linguistic and philosophy 9, 405-426.

Evans, N., 2000. Word Classes in the world's languages. In: Booij, G., Lehmann, C., Mugdan, J., (Eds.), Morphologie/Morphology: ein internationales Handbuch zur Flexion und Wortbildung/an International Handbook on Inflection and WordFormation, Vol. 1. Walter de Gruyter, Berlin, pp. 708-32.

Fenton, D., 2010. Multiple functions, multiple techniques: The role of methodology in a study of Zapotec determiners. In: Berez, A., Mulder, J., Rosenblum, D., (Eds.), Fieldwork and Linguistic Analysis in Indigenous Languages of the Americas. University of Hawai'i Press, Honolulu, pp. 125-145.

Feuillet, J., 1999. Grammaire historique du bulgare. Institut d’études slaves, Paris.

Fleischman, S., 1989. Temporal Distance: A basic linguistic metaphor. Studies in Language 13, 1-50.

Flier, M., 1974. Aspects of nominal determination in Old Church Slavonic. Mouton, The Hague.

Franks, S., King, T. H., 2000. A Handbook of Slavic Clitics. Oxford University Press, Oxford.

Friedman, V., 2002. Macedonian. Lincom, Muenchen.

Friedman, V., 2004. The typology of Balkan evidentiality and areal linguistics. In: Tomić, O., (Ed.), Balkan syntax and semantics. Benjamins, Amsterdam, pp. 101-134.

Gălăbov, I., 1950. Za člena v bălgarskija ezik. Izvestija na narodnija muzej v Burgas 1, 171227.

Haspelmath, M., 1997. From space to time - Temporal adverbials in the World's Languages. Lincom Europa, Muenchen / Newcastle.

Haude, K., 2006. A Grammar of Movima. Radboud University Nijmegen.

Heine, B., Claudi, U., Hünnemeyer, F., 1991. From cognition to grammar: Evidence from African languages. In: Traugott, E., Heine, B., (Eds.), Approaches to grammaticalization. John Benjamins, Amsterdam, pp. 149-188.

Janda, L., 2002. Concepts of case and time in Slavic. Glossos 3.

Kabasanov, S., 1963. Edin starinen bălgarski govor. Tixomirskijat govor. Izd. na Bă lgarskata akademija na naukite, Sofia.

Kasatkina, R., 2008. Artikli, predartikli i psevdoartikli v russkom iazyke. In Proccedings of the Russian delegation at the XIVe International Congress of Slavists, pp. 305-321.

Kanevska-Nikolova, E., 2001. Govorăt na selo Momčilovci, Smoljensko - polovin vek pokăsno. Meždunarodno sociolingvističesko družestvo, Sofia.

Kanevska-Nikolova, E., 2006. Trojnoto členuvane v rodopskite govori. Univ. Izdatelstvo Paisij Xilendarski, Plovdiv.

Klein, W., 1994. Time in language. Routledge, London.

Kokkas, N., 2004a. Uchem so Pomatsko. Pakethra, Xanthi. 
Kokkas, N., 2004b. Uchem so Pomatsko B. Texts. Pakethra, Xanthi.

Koneski, B., 1954. Gramatika na makedonskiot literaturen jazik. 2. Državno knigoiztatelstvo, Skopje.

Krapova, I., 2010. Bulgarian relative and factive clauses with an invariant complementizer. Lingua 120, 1240-1272.

Lakoff, R., 1974. Remarks on this and that. Chicago Linguistic Society 10, 345-356.

Leafgren, J., 2002. Degrees of Explicitness. Information Structure and the Packaging of Bulgarian Subjects and Objects. John Benjamins, Amsterdam/Philadelphia.

Lecarme, J., 1999. Nominal Tense and Tense Theory. In: Corblin, F., Marandin, J.-M., Sorin, C., (Eds.), Empirical Issues in Formal Syntax and Semantics 2, Selected papers from the Colloque de Syntaxe et Sémantique à Paris (CSSP 1997). Holland Academic Graphics, The Hague, pp. 333-354.

Lecarme, J., 2004. Tense in Nominals. In: Guéron, J., Lecarme, J., (Eds.), The Syntax of Time. MIT Press, Cambridge, pp. 440-475.

Levinson, S., 2004. Deixis and pragmatics. In: Horn, L., Ward, G., (Eds.), The Handbook of pragmatics. Blackwell, Oxford, pp. 97-121.

Lunt, H., 1952. Grammar of the Literary Macedonian Language. Skopje.

Lyons, J., 1977. Semantics. Cambridge University Press, Cambridge.

Lyons, C., 1999. Definitiness. Cambridge University Press, Cambridge.

Manning, P., 2002. On social deixis. Anthropological Linguistics 43/1, 54-100.

Marchello-Nizia, C., 2006. From personal deixis to spatial deixis. In: Hickmann, M., Robert, S., (Eds.), Space in languages: linguistic systems and cognitive categories. John Benjamins, Amsterdam/Philadelphia, pp. 103-120.

Minova-Gurkova, L., (Ed.), 1997. Makedonski jazik. Prosvetno delo, Skopje.

Mirčev, K., 1964. Za člennite formi v srednobălgarskite pametnici. Izvestija na Instituta za Bălgarski ezik 11, 231-234.

Mladenov, M., 1990. Ima li v bălgarskija ezik dvojno členuvane? Bălgarski ezik 40/30, 229231.

Mladenova, O., 2007. Definiteness in Bulgarian. Mouton de Gruyter, Berlin, New York.

Musan, R., 1999. Temporal interpretation and information structure of noun-phrases. Linguistics and philosophy 22/6, 621-661.

Nordlinger, R., Sadler L., 2004. Nominal tense in a crosslinguistic perspective. Language 80/4, 776-806.

Parker, S., 1999. On the behavior of definite articles in Chamicuro. Language 75/3, 552-562.

Reichenbach, H., 1947. Elements of Symbolic Logic. Macmillan, New York.

Robert, S., 2006. Deictic space in Wolof. In: Hickmann, M., Robert, S., (Eds.), Space in languages: linguistic systems and cognitive categories. John Benjamins, Amsterdam/Philadelphia, pp. 155-174.

Rogo, A., 2002. Pomakika dhimotika tragoudhia tis Thrakis. Tameion Thrakis, Xanthi.

Rose, F., in press, Mojeño Trinitario. In: Crevels, M., Muysken, P., (Eds.), Lenguas de Bolivia. La Paz, Plural Editores.

Skopeteas S., Fiedler, I., Hellmuth, S., Shwarz, A., Stoel, R., Fanselow, G., Féry, C., Krifka, M., 2006. Questionnaire on information structure. Audiovisuelles Zentrum der Universität Potsdam und sd:k Satz Druck GmbH Potsdam.

Sobolev, A. N., 2001. Bolgarskij shirokolykskij govor: Sintaksis, Leksika duchovnoj kul'tury, Teksty. Biblion Verlag, Marburg.

Sobolev, A. N., (Ed.), 2005. Малый диалектологический атлас балканских языков, Том I. Категории имени существительного. Biblion Verlag, Muenchen.

Sonnenhauser, B., 2009. The Macedonian Tripartite Article: A Discourse-Oriented Account. Makedonski Jazik LX, 123-136. 
Svane, G., 1961-62. O sintaksičeskom primenenii bolgarskogo člena v XIII veke. A. Čergedskie teksty. B. Dobrejšovo evangelie. Scando-Slavica 7, 8, 233-51, 24-8.

Theoharidis, P., 1995. Pomakoi. Pakethra, Xanthi.

Theoharidis, P., 1996a. Grammatiki tis Pomakikis glossas. Aigeiros, Thessaloniki.

Theoharidis, P., 1996b. Ellino-Pomakiko lexiko. Aigeiros, Thessaloniki.

Theoharidis, P., 1996c. Pomako-Elliniko lexiko. Aigeiros, Thessaloniki.

Traugott, E. C., 1978. On the expression of spatio-temporal relations in language. In:

Greenberg, J., Ferguson, C., Moravcsik, E., (Eds.), Universals of human language, vol. 3: Word structure. Stanford University Press, Stanford, pp. 369-400.

Tomić, O., 1996. The Balkan Slavic nominal clitics. In: Halpem, A., Zwicky, A., (Eds.), Approaching second: Second position clitics and related phenomena, 51. CSLI, Stanford, CA, pp. l-535.

Topolinjska, Z., 2006. Trojniot člen: da ili ne? Juznoslovenski filolog 62, 7-15.

Traugott, E., Ter Meulen, A., Reilly, J., Ferguson, C. A., (Eds.), 1986. On conditionals. Cambridge University Press, Cambridge.

Vaillant, A., 1964. Manuel du vieux slave. Institut d'études slaves, Paris.

Vidal, A., Klein, H. E., 1998. Irrealis in Pilagá and Toba? Syntactic versus Pragmatic Coding Source. Anthropological Linguistics 40/2, 175-197. 